\title{
Soldiers' Hypertension Prevalence in Military Garrisons in the City of Conakry
}

\author{
Alpha Oumar Bah1 ${ }^{*}$ Mamadou Foinké Bah², Fatoumata Binta Fofana², Mariama Beavogui ${ }^{3}$ \\ ${ }^{1}$ Departement of Nephrology, Donka National Hospital, Conakry, Guinea \\ ${ }^{2}$ Departement of Armies' Health, Conakry, Guinea \\ ${ }^{3}$ Departement of Cardiology, Ignace Deen National Hospital, Conakry, Guinea \\ Email: ^bahalphaoumar1@gmail.com
}

How to cite this paper: Bah, A.O., Bah, M.F., Fofana, F.B. and Beavogui, M. (2016) Soldiers' Hypertension Prevalence in Military Garrisons in the City of Conakry. Open Journal of Nephrology, 6, 132-137. http://dx.doi.org/10.4236/ojneph.2016.64016

Received: October 7, 2016

Accepted: November 19, 2016

Published: November 22, 2016

Copyright $\odot 2016$ by authors and Scientific Research Publishing Inc. This work is licensed under the Creative Commons Attribution International License (CC BY 4.0).

http://creativecommons.org/licenses/by/4.0/

\begin{abstract}
High blood pressure (HBP) is a public health problem worldwide. The objective of this study is to determine the prevalence of hypertension in military garrisons in Conakry, the capital. Material and Methods: The study was done in military garrisons. The data concern 1025 soldiers. This prospective and cross-sectional study took place from 13 November 2014 to 13 February 2015. Only the military who had agreed to participate in the study were included. Sociodemographic, clinical data and urine dipsticks were collected. Results: Among 1025 soldiers, 222 cases of HPB were observed, that was $21.66 \%$. They were 193 men $(86.94 \%)$ and 29 women $(13.06 \%)$. The mean age was 46.05 years (range: 18 - 77 years). HPB cases were discovered in 155 soldiers $(69.82 \%)$ in random observations. Following the grade of hypertension: 124 were of grade I, 62 of grade II, 35 of grade III and 1 case of isolated systolic hypertension was identified. Urinary dipstick tests showed that, 3 patients had proteinuria, 26 patients suffered from leucocyturia, 11 patients suffered from glycosuria and 1 case of hematuria was also identified. More than half of the soldiers (41\%) were in the army. Officers were strongly affected $(80.18 \%)$, followed by non-commissioned officers $(17.12 \%)$ and finally enlisted men (2.70\%). Risk factors were multiple: $78.82 \%$ ate very salty food; emotional stress; physical inactivity was observed in over half of the cases. Conclusion: This study gives an overall picture of the prevalence of hypertension in the military in Guinea. The discovery of the symptom lies on the systematic measurement of blood pressure.
\end{abstract}

\section{Keywords}

High Blood Pressure, Military, Prevalence, Conakry 


\section{Introduction}

High blood pressure (HBP) is currently recognized as a public health problem worldwide due to its frequency and the fact that risks of cardiovascular and renal diseases are attached to it. More than a quarter $(26.4 \%)$ of adults worldwide are hypertensive, and this proportion is expected to reach $29.2 \%$ in 2025 , nearly 1.6 billion hypertensive patients [1].

In every African country, HBP is worrying and represents $20 \%$ to $30 \%$ of all hospital admissions [2]. Between 1980 and 2008, while the prevalence of hypertension in adults over 25 years has decreased in the world and in regions of the World Health Organization, it has on the contrary increased in African regions [3].

Hypertension in black Africans is more severe and develops earlier with a higher prevalence and more serious complications than in Europeans [4]. The hospital prevalence of hypertension at the nephrology department was $42.9 \%$ in Guinea [5]. Its prevalence in the general population had never been measured in the Guinean army. It is therefore essential to detect and control hypertension. The objective of this study is to measure the prevalence of hypertension in military garrisons in the capital of Guinea, the city of Conakry.

\section{Framework, Material and Methodology}

The realization of the study focused on the military garrisons in the city of Conakry which are composed of the Almamy Samory Tourecamp, the main air force base, the General Command of Gendarmerie and the Navy. The data are those of the 1025 soldiers from all military units.

This is a prospective, cross-sectional study with analytical objectives conducted on a 3-month period from 13 November 2014 to 13 February 2015.

Selection criteria: the target population covered all military garrisons in the city of Conakry. Target population included soldiers from chosen garrisons who agreed to participate in the study. Soldiers who were absent during the study period, and those who did not agree to participate in the study or did not belong to one of the targeted garrisons, were not included into the study.

During the screening, the following information was recorded on a standardized form:

1) Data of the interrogation: they included sociodemographic data, data on lifestyle mainly on the consumption of highly salted foods estimated at over $12 \mathrm{~g}$ per day, stress, tobacco, alcohol, diabetes, prolonged consumption of certain medications (corticosteroids, anti-inflammatory drugs, analgesics), and the practice of physical activity.

2) Data of physical examination: they related to the measurement of blood pressure, weight, size and examination of urine by dipstick in search of proteins, blood, glucose, leukocytes and nitrites.

The measurement of blood pressure was performed with a blood pressure monitor Omron $^{\circledR}$, M5-I. The measurement was carried out after 10 minutes of rest in both arms in a sitting and standing positions on 2 occasions, with adequate armband respective 
to the size of the arm, the measurement was not taken directly after meals, emotional reactions, physical exercise or smoking. Clinical examination was repeated after 3 months.

Hypertension was categorized according to the WHO classification [6]. It was defined as systolic blood pressure (SBP) greater than or equal to $140 \mathrm{~mm} \mathrm{Hg}$ and/or diastolic blood pressure (DBP) greater than or equal to $90 \mathrm{~mm} \mathrm{Hg}$, or the taking of an anti-hypertensive effect drug in a patient with SBP $<140 \mathrm{mmHg}$ and $\mathrm{DBP}<90 \mathrm{~mm} \mathrm{Hg}$ previously diagnosed as hypertensive.

Body mass index (BMI) was calculated from measurements of weight and height $\left(\mathrm{P} / \mathrm{T}^{2}\right)$. Obesity was defined for BMI values $\geq 30 \mathrm{~kg} / \mathrm{m}^{2}$.

The analysis was performed according to age, sex, education level, unit, military rank, hypertension risk factors, the degree of hypertension and the results of dipsticks.

Statistical analysis: The different variables of the sample were described by the percentage of the variable in the categories, by the mean and standard deviation for continuous quantitative variables.

ETHICS: The respondents were informed of the objectives and interests of the study. The confidentiality of the interview was guaranteed. Informed consent of each interviewee was made. All current and/or past hypertensive soldiers with anomalies according to dipsticks analysis were referred to the Nephrology Department at Donka National Hospital.

\section{Results}

The study focused on 1025 soldiers based in the Guinean army. Among them, 222 cases of hypertension were detected say $21.66 \%$. They were 193 men (86.94\%) and 29 women $(13.06 \%)$, a sex ratio of 6.65 . The average age of hypertensive soldiers was of 46.05 years with extremes of 18 and 77 years. Hypertension increases with age, with a maximum between the ages of 48 and 67 years (Table 1).

According to the level of education, 90 hypertensive soldiers had higher education degrees (40.54\%) against 102 for high school level (45.95\%), 18 for primary school level (8.11\%) and 12 had never attended school (5.4\%). Note that no hypertensive soldier had a postgraduate degree (Table 2 ). Among the four military units surveyed, more than half of the soldiers (55.41\%) were in the army, followed by the navy, then the air force and finally the gendarmerie; but when considering proportion of surveyed units, hypertension is more common in the Navy (Table 3). Officers were strongly affected $(80.18 \%)$, followed by non-commissioned officers (17.12\%) and finally enlisted men (2.70\%) (Table 4).

For 155 soldiers, hypertension was newly discovered say $69.82 \%$. As for medical history, 67 soldiers were known to be hypertensive and 13 were known to be diabetics, 57 were smokers, 23 were alcoholics and 14 consumed both alcohol and tobacco. The grade of hypertension: 124 were grade I, 62 grade II, 35 grade III and 1 case of isolated systolic hypertension was detected. Urinary dipstick observations showed that, 3 patients had proteinuria, 26 patients suffered from leucocyturia, 11 from glycosuria and 1 
case of hematuria was also identified. Risk factors were many; $78.82 \%$ ate very salty food; emotional stress; physical inactivity was observed in over half of the cases (Figure 1). These risk factors are important because more than half of hypertensive patients had at least one risk factor.

Table 1. Distribution of hypertensive soldiers by age.

\begin{tabular}{cccc}
\hline Age (year) & Number & HTA & $\%$ \\
\hline $18-27$ & 201 & 7 & 0.34 \\
$28-37$ & 226 & 39 & 17.25 \\
$38-47$ & 182 & 53 & 29.12 \\
$48-57$ & 160 & 99 & 61.87 \\
$58-67$ & 31 & 23 & 74.19 \\
$68-77$ & 3 & 1 & 33.33 \\
78 and older & 1 & 0 & \\
Total & 1025 & 222 & \\
\hline
\end{tabular}

Table 2. Distribution of hypertensive soldiers by education level.

\begin{tabular}{cccc}
\hline Education level & Number & HTA & $\%$ \\
\hline Graduate & 429 & 90 & 20.97 \\
High school & 466 & 102 & 21.88 \\
Primary school & 75 & 18 & 24 \\
No education & 55 & 12 & 21.81 \\
Total & 1025 & 222 & \\
\hline
\end{tabular}

Table 3. Distribution of hypertensive soldiers by unit.

\begin{tabular}{cccc}
\hline Units & Number & HTA & $\%$ \\
\hline Army & 481 & 123 & 25.57 \\
Air force & 200 & 24 & 12 \\
National marine & 179 & 55 & 30.72 \\
Gendarmerie & 165 & 20 & 12.12 \\
Total & 1025 & 222 & \\
\hline
\end{tabular}

Table 4. Distribution of hypertensive soldiers by military rank.

\begin{tabular}{cccc}
\hline Military rank & Number & HTA & $\%$ \\
\hline Officer & 461 & 178 & 80.18 \\
Non-commissioned officers & 346 & 38 & 17.12 \\
Enlisted men & 218 & 6 & 2.70 \\
Total & 1025 & 222 & 100 \\
\hline
\end{tabular}




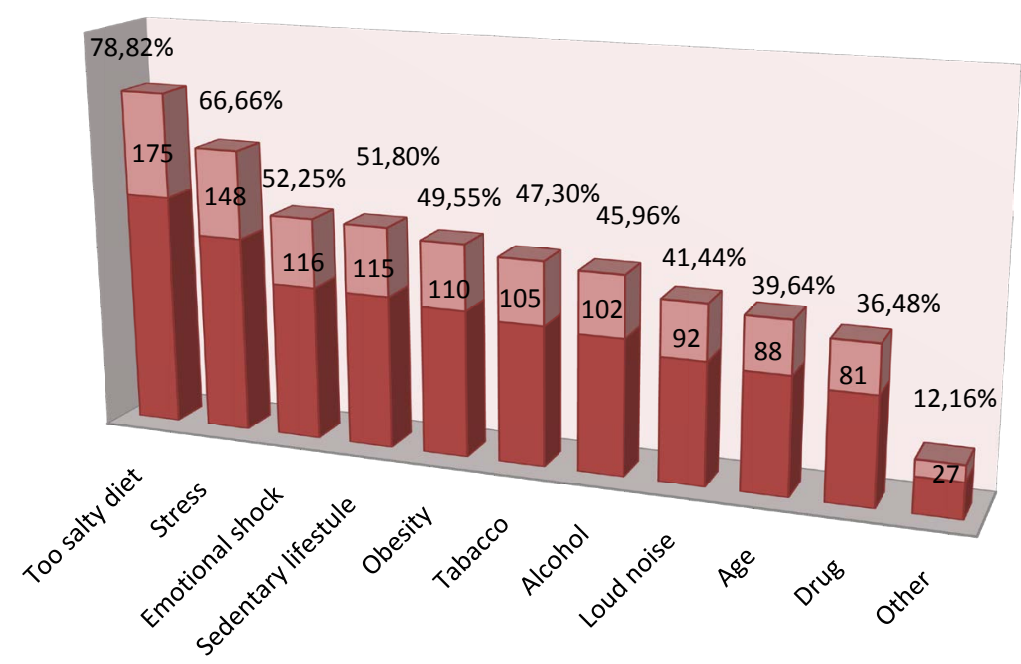

Figure 1. Other: Greasy foods, heredity.

\section{Discussion}

Annual systematic medical visits are not mandatory in the Guinean military. Thus, we decided to screen hypertension in the garrisons of the capital city of Conakry. This study is the first survey conducted on a sample of the Guinean army. It was a crosssectional survey. To obtain statistically representative figures, we surveyed 1025 soldiers. These subjects were informed orally and in writing in the relevance of the study and gave their consent. The peculiarity of the military population in our country is its homogeneity. It is predominantly dominated by men (87\%). This can be explained by the low representation of women in the military population, but also the harsh duties devolved on soldiers in their assignments, often incompatible with the physical condition of women.

The prevalence of hypertension was $21.66 \%$. Few studies have examined the prevalence of hypertension in the military [7]. In India, in a population of police officers, $34.5 \%$ were hypertensive [8].

A group of American and British researchers wanted to assess the current state of this problem in the world and to estimate its prevalence in 2025. Based on data from 30 regional or national studies, it appears that $26.4 \%$ of the 2000 s adult population was hypertensive for an estimated total of 972 million people, 333 million from developed countries and 639 million in developing countries. In 2025, researchers estimated that $29.2 \%$ of the adult population will be hypertensive that represents 1.56 billion people, with an increase of $60 \%$ in 25 years [9]. It therefore appears that hypertension is a major worldwide public health problem.

In black Africa there is a great disparity in the prevalence of high blood pressure; it was $28.05 \%$ in urban areas of Antananarivo in 2009 [10], 32.5\% in Brazzaville in 2004 [11] and 29.7\% in 2001 in a professional environment in Abidjan [12]. According to the WHO, the prevalence of hypertension in the Democratic Republic of Congo is estimated at $38.5 \%$ for men and $33.3 \%$ among women [3]. 


\section{Conclusion}

This study gives an overall picture of the prevalence of hypertension in the military population in Guinea. Many hypertensive individuals did not known their blood pressure status at the beginning of the study as clinical signs of hypertension were totally absent. The absence of early clinical warning signs results in delay of awareness of the pathology by the patient as well as primary prevention actions that can prevent cardiovascular complications. The diagnosis of symptoms lies on the systematic measurement of blood pressure. The data provided by the study will serve as a framework in developing a national integrated and control program of hypertension in the military.

\section{Conflict of Interest}

The script I'm about to present is original and represents my work and that of my coauthors. No part of the manuscript (text, tables, and figures) has been copied or borrowed from an existing material.

\section{References}

[1] Kearney, P.M., Whelton, M. and Reynolds, K. (2005) Global Burden of Hypertension: Analysis of Worldwide Data. The Lancet, 365, 217-223.

http://dx.doi.org/10.1016/S0140-6736(05)70151-3

[2] Touze, J.E. (2007) Les maladies cardiovasculaires et la transition épidémiologique. Médecine Tropicale, 67, 541-542.

[3] Organisation Mondiale de la Santé (2012) Statistiques sanitaires mondiales. Genève.

[4] Guy, A. and Bernard, L. (2007) Particularités de l'HTA du sujet noir africain.

[5] Bah, A.O., Balde, M.S., Diallo, O.B. and Kimso, O. (2016) Late Nephrology Case Management and Morbidity Due to Chronic Renal Failure, Case of Guinea. Health, 8, 805-812. http://dx.doi.org/10.4236/health.2016.89085

[6] World Health Organization/International Society of Hypertension (2003) Statement on Management of Hypertension. Journal of Hypertension, 21, 1983-1992.

[7] Munyapara, S.A., Mundu, M.G., Tshienda, T.J., Batina, A.S. and Likwela, J.L. (2014) Facteurs de risque de l'hypertension artérielle chez les militaires congolais de la garnison de Kinshasa. Revue Médicale des Grands Lacs, 3, Numéro 1.

[8] Ganesh, K.S., Naresh, A.G. and Bammigatti, C. (2014) Prevalence and Risk Factors of Hypertension among Male Police Personnel in Urban Puducherry, India.

[9] Kearney, P.M., Whelton, M., Reynolds, K., et al. (2005) Global Burden of Hypertension: Analysis of Worldwide Data. The Lancet, 365, 217-223. http://dx.doi.org/10.1016/S0140-6736(05)70151-3

[10] Rabarijaona, L.M.P.H., Rakotomalala, D.P., Rakotonirina, EL-C.J., Rakotoarimanana, S. and Randrianasolo, O. (2009) Prévalence et sévérité de l'hypertension artérielle de l'adulte en milieu urbain à Antananarivo. Revue d Anesthésie-Réanimation et de Médecine d Urgence, 1, 24-27.

[11] Kimbally-Kaky, G., Gombet, T., Bolanda, J.D. et al. (2006) Prévalence de l'hypertension artérielle à Brazzaville. Cardiologie Tropicale, 32, 43-46.

[12] Koffi, N.M., Sally, S.J., Kouame, P., Silue, K. and Diarra Nama, A.J. (2001) Facies de l'hypertension artérielle en milieu professionnel à Abidjan. Médecine d'Afrique Noire, 48, No. 6 . 
Submit or recommend next manuscript to SCIRP and we will provide best service for you:

Accepting pre-submission inquiries through Email, Facebook, LinkedIn, Twitter, etc. A wide selection of journals (inclusive of 9 subjects, more than 200 journals)

Providing 24-hour high-quality service

User-friendly online submission system

Fair and swift peer-review system

Efficient typesetting and proofreading procedure

Display of the result of downloads and visits, as well as the number of cited articles

Maximum dissemination of your research work

Submit your manuscript at: http://papersubmission.scirp.org/

Or contact ojneph@scirp.org 